\title{
Residual Effect of Preceding Rice Herbicide on Weed Control, Growth and Productivity of Succeeding Okra in Madurai District of Tamil Nadu
}

\author{
N. Bommayasamy and C.R. Chinnamuthu' ${ }^{1}$ \\ ICAR-Central Island Agricultural Research Institute, Port Blair-744 105, India \\ ${ }^{1}$ Department of Agronomy, Tamil Nadu Agricultural University, Coimbatore-641 003, India \\ E-mail: samygs81@yahoo.co.in
}

\begin{abstract}
An experiment was conducted at Agricultural College \& Research Institute, Tamil Nadu Agricultural University, Madurai during rabi 2016 with a view to study the residual effect of preceding rice herbicide on weed control efficiency, growth and productivity of succeeding okra. Rice herbicide residue exerted significant difference in grasses, sedges and broad leaved weeds density at 20 DAS. In grass, the lowest weed density of 11.67 weeds $/ \mathrm{m}^{2}$ was registered under residual effect of butachlor at $1.25 \mathrm{~kg} \mathrm{ha}^{-1}$ on 3 DAT fb HW on 40 DAT in rice + HW twice at 20 and 40 DAS in okra. Similar trend was also observed in sedges and broad leaved weeds. The same treatment recorded higher plant height of $21.7,53.1$ and $92.7 \mathrm{~cm}$ and DMP of 624,3296 and $9481 \mathrm{~kg} \mathrm{ha}^{-1}$ at 30,60 and 105 days respectively and the fruit yield of $15.37 \mathrm{t} \mathrm{ha} \mathrm{H}^{-1}$ were recorded. It is registered 83.0 and $97.8 \%$ higher fruit yield than residual effect of oxadiargyl loaded with zeolite on 3 DAT and oxadiargyl loaded with biochar on 3 DAT respectively.
\end{abstract}

Keywords: Herbicide residue, Okra, Weed density, Weed control efficiency, Yield

Okra is most important vegetable crop in tropical and sub-tropical climatic condition of the world. India ranks first in production of okra. The production is 6.47 million tonnes from a cultivable area of 5.28 million hectares with productivity of $11.63 \mathrm{~m}$ tonnes per hectare (NHB 2019) and productivity is lower owing to many reasons, of which poor input use efficiency, biotic and abiotic stresses are more important. Among biotic stress, weeds cause yield reduction of 40 to $90 \%$ because of its slow growth during initial stage, weeds take advantage of moisture, nutrient and environmental conditions to suppress the growth (Jalendhar et al 2016, Sah et al 2018), crop remains week and unhealthy, this results in the reduction of yield and quality of fruit. Increasing population pressure has forced to enhance food productivity with limited resources. Intensive agriculture is an alternative way to meet the food demand of growing population. In tropical condition, weeds are major constraint in the food production. Manual weeding is more effective method of weed control in okra, but its time consuming and costlier during critical stage. Because of that, most of the farmers switch over to adopt chemical weed control methods which reduced the drudgery and cost of weeding. The increased use of chemical herbicides has polluted the environment, adversely affects the soil microbes and caused herbicide resistance among weeds (Bhullar et al 2017, Sharma et al 2021). Herbicide usage has created several health and environmental impacts and may disrupt the ecological balance of pest control by natural enemies and led to secondary weed upsurges. Farmers should be taken care while selecting the succeeding crops in rotation. Based on these facts, the present study was carried out to find out the residual effect of preceding rice herbicide on weed control efficiency, growth and productivity of succeeding okra.

\section{MATERIAL AND METHODS}

Experimental details: An experiment was conducted at Agricultural College \& Research Institute, Tamil Nadu Agricultural University, Madurai during rabi 2016 with a view to study the residual effect of preceding rice herbicide on weed control efficiency, growth and productivity of succeeding okra. The soil was sandy loam in texture with low in available nitrogen, medium in available phosphorus and potash. Preceding rice crop experiment lay out in randomized block design was used for succeeding okra with eight treatments and replicated thrice (Table 1).

Agronomic practices: After harvest of rice, Okra hybrid of CO-4 was sown in rice stubbles with the spacing of $45 \mathrm{~cm} \times 30$ $\mathrm{cm}$ during the $1^{\text {st }}$ week of January. Gap filling and thinning was done at 10 DAS and leaving a single healthy plant per hill. Recommended dose of fertilizer 200:100:100 kg NPK hawas applied in the form of urea, super phosphate and muriate of potash. The crop was irrigated immediately after sowing and followed by life irrigation was given on $3^{\text {rd }}$ DAS and subsequent irrigation was given as and when crop required. 
All the other recommended packages were adopted as per the schedule. Observations on crop growth and yield were recorded as per standard procedures. The height of the plant was measured from the bottom of the plant to the tip of the growing point on 30and 60 DAS and at harvest stage of the crop and when the okra fruits attained the stage suitable for vegetable purpose, the fruits were harvested. The yield obtained from each picking was weighed, accounted and summed up to obtain the total fruit yield per plot from which the yield per hectare was worked out and expressed as tha ${ }^{-1}$.

Weed density: The weed count was recorded species wise using $0.5 \mathrm{~m} \times 0.5 \mathrm{~m}$ quadrate from four randomly fixed places in each plot and the weeds falling within the frames of the quadrate were counted, recorded and the mean values were expressed in weeds $/ \mathrm{m}^{2}$. The density of grasses, sedges and broad leaved weeds and the total weeds were recorded at 20 DAS.

Weed dry weight: The weeds falling within the frames of the quadrate $(0.5 \mathrm{~m} \times 0.5 \mathrm{~m})$ were collected, categorized into grasses, sedges and broad leaved weeds, shade dried and later dried in hot-air oven at $80^{\circ} \mathrm{C}$ for $72 \mathrm{hrs}$. The dry weight of grasses, sedges and broad leaved weeds were recorded separately at 20 DAS and expressed in $\mathrm{g} \mathrm{m}^{-2}$.

Weed control efficiency: Weed control efficiency was computed by adopting the formula suggested by Mani et al (1973).

$$
\mathrm{WCE}(\%)=\frac{\mathrm{Wpc}-\mathrm{Wpt}}{\mathrm{Wpc}} \times 100
$$

Where, Wpc- weed dry weight in unweeded control plot $\left(\mathrm{g} \mathrm{m}^{-2}\right)$, Wpt- weed dry weight in treated plot $\left(\mathrm{g} \mathrm{m}^{-2}\right)$.

Root volume and dry weight: As standard procedure suggested by Ahmet and Ali (2009) for the estimation of root volume, the roots of the randomly selected plants were dug out from the plots carefully at 30 and 60 DAS, washed and roots were measured by the volume of water displaced in the measuring cylinder, the root volume was measured and expressed in $\mathrm{cm}^{3}$. The roots after the assessment of volume were sun dried and then oven dried for 8 hours at $65 \pm 5^{\circ} \mathrm{C}$ and the dry weight of samples were recorded and expressed in $\mathrm{g}$ plant $^{-1}$.

Statistical analysis: The data pertaining to weeds were transformed to square root of $\sqrt{ } \mathrm{x}+2$ and statistically analyzed by following the method of Gomez and Gomez (2010). All the observations were statistically analyzed for its test of significance in the individual treatment wise and mean data is presented.

\section{RESULTS AND DISCUSSION}

Weed density and weed control efficiency: Rice herbicide residue exerted significant difference in grass, sedges and broad leaved weed (BLW) density at 20 DAS (Table 2). Weed free check was recorded distinctly the lowest grass, sedges and BLW weed density at 20 DAS. Among the weed control treatments, residual effect of oxadiargyl loaded with zeolite on 3 DAT recorded significantly lower grass weed density of 11.67 weeds $\mathrm{m}^{-2}$ which at par with residual effect of butachlor at $1.25 \mathrm{~kg} \mathrm{ha}^{-1}$ on 3 DAT fb hand weeding (HW) on 40 DAT in rice + HW twice at 20 and 40 DAS in okra. In sedges, the lowest weed density of 5.67 weeds $\mathrm{m}^{-2}$ was registered in residual effect of butachlor at $1.25 \mathrm{~kg} \mathrm{ha}^{-1}$ on $3 \mathrm{DAT} \mathrm{fb} \mathrm{HW}$ on 40 DAT in rice + HW twice at 20 and 40 DAS in okra. This was followed by residual effect of oxadiargyl loaded with zeolite on 3 DAT (12.00 weeds $\left.\mathrm{m}^{-2}\right)$. Similar trend was also observed in broad leaved weed.

Residual effect of butachlor at $1.25 \mathrm{~kg} \mathrm{ha}^{-1}$ on 3 DAT fb $\mathrm{HW}$ on 40 DAT in rice $+\mathrm{HW}$ twice at 20 and 40 DAS in okra recorded $83.1,87.5$ and $92.9 \%$ reduced grass, sedges and BLW weed density respectively as compared to weedy check. It might be due to effective control of weeds in preceding rice followed by two hand weeding reduced the soil weed seed bank. Similar findings were reported by Bommayasamy et al (2018). Weed control efficiency of grass was higher in residual effect of oxadiargyl loaded with zeolite on 3 DAS whereas, residual effect of oxadiargyl encapsulated with water soluble polymer on 3 DAT recorded higher sedges and BLW weeds control efficiency.

Table 1. Rice and okra crop experiment lay out in randomized block design

\begin{tabular}{ll}
\hline Rice herbicide residue $(R H R)$ & Succeeding okra crop \\
\hline$T_{1}$ - Oxadiargyl loaded with biochar at 3 DAT & $T_{1}$ - Residual effect of preceding rice herbicide \\
$T_{2}$-Oxadiargyl loaded with zeolite on 3 DAT & $\mathrm{T}_{2}$ - Residual effect of preceding rice herbicide \\
$\mathrm{T}_{3}$-Oxadiargyl encapsulated with starch on 3 DAT & $\mathrm{T}_{3}$ - Residual effect of preceding rice herbicide \\
$\mathrm{T}_{4}$-Oxadiargyl encapsulated with water soluble polymer on 3 DAT & $\mathrm{T}_{4}$ - Residual effect of preceding rice herbicide \\
$\mathrm{T}_{5}$ - Oxadiargyl at 100 $\mathrm{g} \mathrm{ha}^{-1}$ on 3 DAT & $\mathrm{T}_{5}$ - Residual effect of preceding rice herbicide \\
$\mathrm{T}_{6}$-Butachlor at 1.25 $\mathrm{kg} \mathrm{ha}^{-1}$ on 3 DAT fb hand weeding on 40 DAT & $\mathrm{T}_{6}$-Hand weeding at 20 \& 40 DAS \\
$\mathrm{T}_{7}$-Weed free check & $\mathrm{T}_{7}$-Weed free check \\
$\mathrm{T}_{8}$-Weedy check & $\mathrm{T}_{8}$-Weedy check \\
\hline
\end{tabular}


Plant height: Weed control treatments significantly altered the plant height of okra (Table 3). At 30 DAS, residual effect of butachlor at $1.25 \mathrm{~kg} \mathrm{ha}^{-1}$ on 3 DAT fb HW on 40 DAT in rice + $\mathrm{HW}$ twice at 20 and 40 DAS in okra recorded the highest plant height of 22.6 and $52.4 \mathrm{~cm}$ on 30 and 60 DAS respectively. The least plant height was registered with weedy check treatment and was followed by treatments were residual effect of oxadiargyl encapsulated with water soluble polymer on 3 DAT recorded and it was comparable with residual effect of oxadiargyl loaded with zeolite on 3 DAT. Similar trend was observed at harvest stage of the crop.

Plant dry matter production: Weed free check exhibited its superiority by registering the highest DMP of 731,4005 and $13133 \mathrm{~kg} \mathrm{ha}^{-1}$ at 30,60 DAS and 105 DAS, respectively.
Among various weed control treatments, at $30 \mathrm{DAS}$, residual effect of butachlor at $1.25 \mathrm{~kg} \mathrm{ha}^{-1}$ on $3 \mathrm{DAT}$ fb HW on 40 DAT in rice + hand weeding twice at 20 and 40 DAS in okra recorded higher DMP of 624 and $3120 \mathrm{~kg} \mathrm{ha}^{-1}$ on 30 and 60 DAS respectively. It was on par with residual effect of oxadiargyl encapsulated with water soluble polymer on 3 DAT, oxadiargyl loaded with zeolite on 3 DAT and oxadiargyl loaded with biochar on 3 DAT. These treatments were on par with one another. Similar trend was also observed at harvest stage of the crop. It might be owing to controlled release of encapsulated herbicide reduced movement of herbicide in soil and keeping the sizable portion of the active ingredient in the surface soil layer for longer period of time. Better vegetative growth in terms of plant height and more canopies

Table 2. Residual effect of preceding rice herbicide of oxadiargyl on weeds density and weed control efficiency at 20 DAS of succeeding okra

\begin{tabular}{|c|c|c|c|c|c|c|}
\hline \multirow[t]{2}{*}{ Treatments } & \multicolumn{3}{|c|}{ Weed density (weeds $\mathrm{m}^{-2}$ ) } & \multicolumn{3}{|c|}{ Weed control efficiency } \\
\hline & Grass & Sedges & BLW & Grass & Sedges & BLW \\
\hline $\mathrm{T}_{1}$-Oxadiargyl loaded with biochar on 3 DAT & $\begin{array}{c}4.72 \\
(20.33)\end{array}$ & $\begin{array}{c}4.58 \\
(19.00)\end{array}$ & $\begin{array}{c}2.23 \\
(3.00)\end{array}$ & 84.2 & 50.6 & 47.0 \\
\hline $\mathrm{T}_{2}$-Oxadiargyl loaded with zeolite on 3 DAT & $\begin{array}{c}3.70 \\
(11.67)\end{array}$ & $\begin{array}{c}3.74 \\
(12.00)\end{array}$ & $\begin{array}{c}3.05 \\
(7.33)\end{array}$ & 90.2 & 56.3 & 63.5 \\
\hline $\mathrm{T}_{3}$-Oxadiargyl encapsulated with starch on 3 DAT & $\begin{array}{c}6.08 \\
(35.00)\end{array}$ & $\begin{array}{c}5.29 \\
(26.00)\end{array}$ & $\begin{array}{c}3.00 \\
(7.00)\end{array}$ & 90.9 & 43.8 & 49.4 \\
\hline $\mathrm{T}_{4}$-Oxadiargyl encapsulated with water soluble polymer on 3 DAT & $\begin{array}{c}4.72 \\
(20.33)\end{array}$ & $\begin{array}{c}4.20 \\
(15.67)\end{array}$ & $\begin{array}{c}2.51 \\
(4.33)\end{array}$ & 84.0 & 56.7 & 66.1 \\
\hline $\mathrm{T}_{5}$-Oxadiargyl at $100 \mathrm{~g} \mathrm{ha}^{-1}$ on 3 DAT & $\begin{array}{c}6.27 \\
(37.33)\end{array}$ & $\begin{array}{c}6.57 \\
(41.33)\end{array}$ & $\begin{array}{c}4.00 \\
(14.00)\end{array}$ & 75.4 & 34.1 & 23.1 \\
\hline $\begin{array}{l}\mathrm{T}_{6}-\text { Butachlor at } 1.25 \mathrm{~kg} \mathrm{ha}^{-1} \text { on } 3 \text { DAT fb HW on } 40 \text { DAT in rice + } \\
\text { HW twice at } 20 \text { and } 40 \text { DAS in okra }\end{array}$ & $\begin{array}{c}3.70 \\
(11.67)\end{array}$ & $\begin{array}{l}2.77 \\
(5.67)\end{array}$ & $\begin{array}{c}1.97 \\
(2.00)\end{array}$ & 82.7 & 74.6 & 59.5 \\
\hline$T_{7}$-Weed free check & $\begin{array}{c}1.41 \\
(0.00)\end{array}$ & $\begin{array}{c}1.41 \\
(0.00)\end{array}$ & $\begin{array}{c}1.41 \\
(0.00)\end{array}$ & 100.0 & 100.0 & 100.0 \\
\hline $\mathrm{T}_{8}-$ Weedy check & $\begin{array}{c}8.40 \\
(69.00)\end{array}$ & $\begin{array}{c}6.88 \\
(45.33)\end{array}$ & $\begin{array}{c}5.47 \\
(28.00)\end{array}$ & - & - & - \\
\hline$C D(P=0.05)$ & 0.46 & 0.38 & 0.56 & - & - & - \\
\hline
\end{tabular}

Figures in parentheses are mean of original values; Data subjected to $\sqrt{ } x+2$ transformations

Table 3. Residual effect of preceding rice herbicide of oxadiargyl on plant height, dry matter production at 30, 60 and $105 \mathrm{DAS}$ of succeeding okra

\begin{tabular}{|c|c|c|c|c|c|c|}
\hline \multirow[t]{2}{*}{ Treatments } & \multicolumn{3}{|c|}{ Plant height $(\mathrm{cm})$} & \multicolumn{3}{|c|}{ Dry matter production $\left(\mathrm{kg} \mathrm{ha}^{-1}\right)$} \\
\hline & 30 DAS & 60 DAS & 105 DAS & 30 DAS & 60 DAS & 105 DAS \\
\hline $\mathrm{T}_{1}$ & 19.6 & 26.3 & 66.2 & 569 & 1482 & 4948 \\
\hline $\mathrm{T}_{2}$ & 20.2 & 35.4 & 67.8 & 577 & 1950 & 6913 \\
\hline $\mathrm{T}_{3}$ & 18.5 & 29.4 & 63.6 & 572 & 1426 & 4868 \\
\hline $\mathrm{T}_{4}$ & 20.8 & 34.9 & 69.9 & 576 & 2776 & 5043 \\
\hline $\mathrm{T}_{5}$ & 16.6 & 30.6 & 56.4 & 562 & 1938 & 4088 \\
\hline $\mathrm{T}_{6}$ & 21.7 & 53.1 & 92.7 & 624 & 3296 & 9481 \\
\hline $\mathrm{T}_{7}$ & 24.4 & 70.2 & 106.2 & 741 & 4147 & 13022 \\
\hline $\mathrm{T}_{8}$ & 14.4 & 24.6 & 43.4 & 551 & 1424 & 3873 \\
\hline$C D(P=0.05)$ & 2.26 & 3.61 & 10.57 & 71 & 274 & 1316 \\
\hline
\end{tabular}


Table 4. Residual effect of preceding rice herbicide of oxadiargyl on LAI and root dry weight at 30 and 60 DAS and fruit yield of succeeding okra

\begin{tabular}{lcccccccccc}
\hline Treatments & \multicolumn{2}{c}{ Leaf area index } & & \multicolumn{2}{c}{$\begin{array}{c}\text { Root volume } \\
\left(\mathrm{cm}^{3} \text { plant }\right.\end{array}$}
\end{tabular}

which reflected through dry matter accumulation of plants. Similar findings were observed by Arjun et al (2018) and Bommayasamy and Chinnamuthu (2019).

Leaf area index: Preceding rice herbicide residue later the leaf area index, distinctly at 30 and 60 DAS (Table 4). Higher leaf area index of 1.15 and 2.33 was recorded at 30 and 60 DAS respectively under weed free check and was followed by residual effect of butachlor at $1.25 \mathrm{~kg} \mathrm{ha}^{-1}$ on 3 DAT fb HW on 40 DAT in rice+ HW twice at 20 and 40 DAS in okra and residual effect of oxadiargyl loaded with zeolite on 3 DAT and might be due to reduction in weed survival and weeds gets covered by soil, while using manual weeding and desiccation of soil surface might have inhibited the weed regeneration. Similar finding was reported by Arunjith and Murali Arthanari (2021) and Bommayasamy and Chinnamuthu (2021).

Root characters: It plays important role in soil water and solute dynamics by modifying the moisture and nutrient uptake pattern in the root zone. The root systems link the plant and soil which is more responsible for the absorption of water and nutrient, anchorage and synthesis of some plant hormones. Root volume and root dry weight of okra was found to be significantly influenced by preceding rice herbicide residue on succeeding okra (Table 4). The highest root dry weight and root volume of $6.41,21.16 \mathrm{~cm}^{3}$ and 3.01 , $6.38 \mathrm{~g} \mathrm{plant}^{-1}$ was recorded under weed free check at 30 and 60 DAS respectively followed by residual effects of butachlor at $1.25 \mathrm{~kg} \mathrm{ha}^{-1}$ on 3 DAT fb HW on 40 DAT in rice+ HW twice at 20 and 40 DAS in okra, oxadiargyl loaded with zeolite on 3 DAT, oxadiargyl loaded with biochar on 3 DAT. This might be due to higher nutrient uptake of okra could be attributed to increased root dry weight and root volume which might have enabled more absorption area reported by Bommayasamy and Durairaj (2018). Selva Rani and Mariappan (2019) reported that adequate quantity of nutrients coupled with adequate moisture might have resulted in higher root proliferation in bhendi under manize-bhendi cropping sequence.

Effect on fruit yield: Weed control treatment showed significantly influenced on okra fruit yield (Table 4). Weed free check recorded significantly higher fruit yield of $24.19 \mathrm{t} \mathrm{ha}^{-1}$. Among the weed control treatments, the higher fruit yield of $15.37 \mathrm{tha}^{-1}$ was recorded under residual effect of butachlor at $1.25 \mathrm{~kg} \mathrm{ha}^{-1}$ on 3 DAT fb HW on 40 DAT in rice + HW twice at 20 and 40 DAS in okra which was 83.0 and $97.8 \%$ higher fruit yield than residual effect of oxadiargyl loaded with zeolite on 3 DAT and oxadiargyl loaded with biochar on 3 DAT respectively. The higher yield may be attributed to less competition of weeds and decrease in their population that helped in increasing the yield attributes which ultimately led to higher yield and also increase number of nodes plant ${ }^{-1}$ yielding maximum number of fruits. Similar results were reported by Rajasree et al (2017). The least fruit yield of $3.27 \mathrm{t}$ $\mathrm{ha}^{-1}$ was recorded in weedy check. It might be due effective weed control results in reduced the crop weed competition to a greater extent and removal of nutrient by weeds. Thus higher nutrient uptake by crops helps in faster growth and development of fruits. Similar results were reported by Patel et al (2017).

\section{CONCLUSION}

The residual effect of oxadiargyl loaded in zeolite applied to the previous rice crop resulted in enhanced weed control efficiency, crop growth attributes, and yield of the okra crop under the manpower scarcity scenario of manual weeding.

\section{REFERENCES}

Ajrun MA, Singh T, Shukla M and Namdeo KN 2018. Integrated nutrient management on growth, yield and quality of okra 
(Abelmoschus exculentus L. Moench). Annals of Plant and Soil Research 20(4): 344-348.

Arunjith $P$ and Murali Arthanari P 2021. Post emergent non chemical formulations for weed management in maize. Indian Journal of Ecology 48(1): 13-17.

Bhullar MS, Kaur N, Kaur P and Gill G 2017. Herbicide resistance in weeds and its management. Agricultural Research Journal 54(4): 436-444.

Bommayasamy $\mathrm{N}$ and Chinnamuthu CR 2019. Residual effect of slow release herbicide formulations on weed and bhendi in the rice-bhendi crop sequence. Madras Agricultural Journal 106(46): 344-348.

Bommayasamy $\mathrm{N}$ and Chinnamuthu CR 2021. Effect of encapsulated herbicides on weed control, productivity and nutrient uptake of rice (Oryza sativa). Journal of Environmental Biology 42(2): 319-325.

Bommayasamy N, Chinnamuthu CR, Venkataraman NS Balakrishnan K, Rathinasamy A and Gangaiah B 2018. Effect of entrapped preceding rice crop herbicide oxadiargyl on growth and yield of succeeding bhendi. International Journal of Current Microbiology and Applied Sciences 7(6): 1915-1921.

Bommayasamy Nand and Durairaj Nallaiah 2018. Influence of nonmonetary inputs on growth, yield and economics of rice under system of rice intensification (SRI). Journal of Pharmacognosy and Phytochemistry 7(3): 3046-3049.

Gomez KA and Gomez AA 2010. Statistical Procedures for Agricultural Research. $2^{\text {nd }}$ Edn. John Wiley and Sons, New York, USA, p 307.

Jalendhar G, Chandra Shekar Reddy K, Srinivas Aand Manohar Rao
A 2016. Effect of integrated weed management practices on growth, yield and it's attributes in okra (Abelmoschus esculentus (L.) Moench) cv. Arka Anamika. International Journal of Science and Nature 7(1): 165-167.

Mani VS, Mala ML, Gautam KC and Bhagavandas 1973. Weed killing chemicals in potato cultivation. Indian Farming 23(1): 1718.

NHB 2019. Indian Horticultural Database 2018-19, National Horticultural Board, Ministry of Agriculture and Farmers Welfare, Government of India.

Patel TU, Zinzala MJ, Patel DD, Patel HH and Italiya AP 2017. Weed management influence on weed dynamics and yield of summer lady's-finger. Indian Journal of Weed Science 49(3): 263-265.

Rajasree V, Sathiyamurthy VA, Shanmugasundaram $T$ and Arumugam T 2017. Integrated weed management on growth, yield and economics in okra (Abelmoschus esculentus (L.) Moench) under Kharif. Madras Agricultural Journal 104(1-3): 81-84.

Sah D, Heisnam P and Pandey AK 2018. Weed management in okra under foot-hill conditions of North Easter Himalaya. Journal of crop and Weed 14(1): 201-204.

Selva Rani A and Mariappan G 2019. Effect of drip irrigation regimes and fertigation levels on growth, yield, quality parameters, nutrient uptake and water use efficiency of bhendi (Ablemoschus esculentus L. Moench). Journal of Pharmacognosy and Phytochemistry 8: 524-527.

Sharma M, Arora K and Sachdev RK 2021. Bio herbicidal potential of essential oil of callistemon: A review. Indian Journal of Ecology 48(1): 252-260.

Received 06 October, 2021; Accepted 28, December, 2021 